\title{
Promotion of water-mediated carbon removal by nanostructured barium oxide/nickel interfaces in solid oxide fuel cells
}

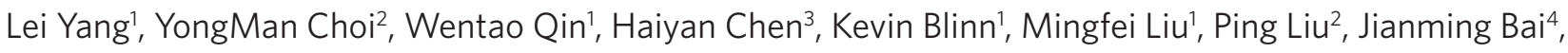
Trevor A. Tyson ${ }^{3} \&$ Meilin Liu'

The existing Ni-yttria-stabilized zirconia anodes in solid oxide fuel cells (SOFCs) perform poorly in carbon-containing fuels because of coking and deactivation at desired operating temperatures. Here we report a new anode with nanostructured barium oxide/nickel $(\mathrm{BaO} / \mathrm{Ni})$ interfaces for low-cost SOFCs, demonstrating high power density and stability in $\mathrm{C}_{3} \mathrm{H}_{8}, \mathrm{CO}$ and gasified carbon fuels at $750^{\circ} \mathrm{C}$. Synchrotron-based $\mathrm{X}$-ray analyses and microscopy reveal that nanosized $\mathrm{BaO}$ islands grow on the $\mathrm{Ni}$ surface, creating numerous nanostructured $\mathrm{BaO} / \mathrm{Ni}$ interfaces that readily adsorb water and facilitate water-mediated carbon removal reactions. Density functional theory calculations predict that the dissociated $\mathrm{OH}$ from $\mathrm{H}_{2} \mathrm{O}$ on $\mathrm{BaO}$ reacts with $\mathrm{C}$ on $\mathrm{Ni}$ near the $\mathrm{BaO} / \mathrm{Ni}$ interface to produce $\mathrm{CO}$ and $\mathrm{H}$ species, which are then electrochemically oxidized at the triple-phase boundaries of the anode. This anode offers potential for ushering in a new generation of SOFCs for efficient, low-emission conversion of readily available fuels to electricity.

\footnotetext{
School of Materials Science and Engineering, Center for Innovative Fuel Cell and Battery Technologies, Georgia Institute of Technology, 771 Ferst Drive, Atlanta, Georgia 30332-0245, USA. ${ }^{2}$ Chemistry Department, Brookhaven National Laboratory, Upton, New York 11973, USA. ${ }^{3}$ Department of Physics, New Jersey Institute of Technology, Newark, New Jersey 07102, USA. ${ }^{4}$ High Temperature Materials Laboratory, Oak Ridge National Laboratory, Oak Ridge, Tennessee 37831, USA. Correspondence and requests for materials should be addressed to M.L. (email: meilin.liu@mse.gatech.edu).
} 
$\mathrm{S}$ olid oxide fuel cells (SOFCs) offer great prospects for the most efficient and cost-effective utilization of hydrocarbons, gasified coal and a wide variety of ample carbonaceous solids (for example, municipal solid waste and biomass) ${ }^{1}$. SOFCs powered by gasified coal are twice as efficient as current coal-fired power plants, potentially reducing $\mathrm{CO}_{2}$ emission by $50 \%$. The critical technical barriers to efficient utilization of these fuels are the vulnerability to coking of the Ni-YSZ (yttria-stabilized zirconia) anodes by dehydrogenation of hydrocarbons and $\mathrm{CO}$ disproportionation at temperatures below $850^{\circ} \mathrm{C}$ (ref. 2), where SOFCs become more competitive economically, $y^{3,4}$.

For direct utilization of hydrocarbon fuels, a number of alternative anodes have been developed, including ceria-based anodes $s^{5-7}$, $\mathrm{La}_{0.75} \mathrm{Sr}_{0.25} \mathrm{Cr}_{0.5} \mathrm{Mr}_{0.5} \mathrm{O}_{3-\delta}$ (with a $\mathrm{Ce}_{0.8} \mathrm{Gd}_{0.2} \mathrm{O}_{2-\delta}$ interlayer) ${ }^{8}, \mathrm{Sr}_{2} \mathrm{Mg}_{1}$ ${ }_{x} \mathrm{Mn}_{x} \mathrm{MoO}_{6-\delta}(0 \leq x \leq 1)^{9}$, doped $(\mathrm{La}, \mathrm{Sr})(\mathrm{Ti}) \mathrm{O}_{3}$ (refs 10,11$)$ and $\mathrm{Ni}-$ $\mathrm{BaZr}_{0.1} \mathrm{Ce}_{0.7} \mathrm{Y}_{0.2-x} \mathrm{Yb}_{\mathrm{x}} \mathrm{O}_{3-\delta}(\mathrm{Ni}-\mathrm{BZCYYb})^{12}$. However, the application of these anodes to actual fuel cell systems is hindered by several critical issues: they are either too expensive to be economically viable (for example, using a noble metal such as Ru or Pd) or outright incompatible with the current YSZ-based SOFCs systems, which have evolved progressively in the past few decades, because of the limited physical, chemical and thermal compatibility of the alternative anodes with YSZ electrolyte during fabrication at high temperatures. For example, it was found that the Ni-BZCYYb anode readily reacts with YSZ at high temperatures, which results in the necessity of implementation of a buffer layer between them in order to avoid formation of electrically insulating phases. Solution infiltration of alternative anode materials into Ni-YSZ anodes has been explored, but showed some success only with utilization of $\mathrm{CH}_{4}$ (ref. 13). In addition, the anode modified by $\mathrm{Ru}-\mathrm{CeO}_{2}$ catalyst achieved the highest reported peak power density of $\sim 0.5 \mathrm{~W} \mathrm{~cm}^{-2}$ in $\mathrm{C}_{3} \mathrm{H}_{8}$ at $750^{\circ} \mathrm{C}$ (ref. 7); however, it is still much lower than that for a typical $\mathrm{H}_{2}$-fueled SOFC operated at the same temperature $\left(\sim 1.0 \mathrm{~W} \mathrm{~cm}^{-2}\right)$.

As an important intermediate in utilization of carbon-containing fuels ${ }^{7}$ and the dominant component of gasified carbon or coal ${ }^{14}, \mathrm{CO}$ has been widely studied in SOFCs under various fuel cell operating conditions $s^{15-18}$. At temperatures below $850^{\circ} \mathrm{C}, \mathrm{CO}$ or CO-rich fuel mixtures readily deactivate Ni-YSZ anodes because of carbon buildup $^{16-18}$, and more so at lower temperatures, as predicted by Boudouard's equilibrium. For example, Jiang and Virkar ${ }^{16}$ found that at $800^{\circ} \mathrm{C}$ a $\mathrm{CO}$ disproportionation reaction occurred on the $\mathrm{Ni}$-YSZ anode when the partial pressure of $\mathrm{CO}$ was greater than $0.8 \mathrm{~atm}$ ( $1 \mathrm{~atm}$ fuel), although a reasonable power density was demonstrated at the initial stage. Accordingly, SOFCs running on gasified carbon or coal through $\mathrm{CO}_{2}$ gasification are often operated at $850^{\circ} \mathrm{C}$ or higher to avoid coking and deactivation ${ }^{14,19}$. Although SOFCs powered by $\mathrm{H}_{2}$-rich syngas derived from steam gasification of carbon may be operated at lower temperatures, the required excess of water not only dilutes the fuel but also increases system complexity and cost because of the need for water management ${ }^{14}$. To date, no stable and desirable power output has been demonstrated by SOFCs with Ni-YSZ-based anodes in $\mathrm{CO}$ or gasified carbon through $\mathrm{CO}_{2}$ gasification below $850^{\circ} \mathrm{C}$. The search for alternative anodes for direct utilization of $\mathrm{CO}$ at intermediate temperatures has progressed slowly and the existing SOFCs powered by $\mathrm{CO}$ and gasified carbon or coal are still inadequate for practical application $s^{14,18-21}$. For example, the cell with $\mathrm{Pd}-\mathrm{La}_{0.8} \mathrm{Sr}_{0.2} \mathrm{Cr}_{0.5} \mathrm{Mn}_{0.5} \mathrm{O}_{3-\delta}-\mathrm{Ce}_{0.48} \mathrm{Zr}_{0.48} \mathrm{Y}_{0.04} \mathrm{O}_{2-\delta}$ anode yielded $\sim 0.45 \mathrm{~W} \mathrm{~cm}^{-2}$ at $800{ }^{\circ} \mathrm{C}$ in $50 \% \mathrm{CO}-50 \% \mathrm{CO}_{2}$ fuel $^{21}$.

Here we report a new anode with nanostructured barium oxide/ nickel $(\mathrm{BaO} / \mathrm{Ni})$ interfaces by vapour deposition of $\mathrm{BaO}$ into $\mathrm{Ni}$ YSZ. In this process, $\mathrm{BaO}$ vapour reacts with the surfaces of $\mathrm{NiO}$, producing a thin layer of $\mathrm{NiO}-\mathrm{BaO}$ compounds on the $\mathrm{NiO}$ surface. On exposure to a fuel, the thin film of $\mathrm{NiO}-\mathrm{BaO}$ compounds is reduced to nanosized $\mathrm{BaO}$ islands distributed on the Ni surface; a continuous $\mathrm{BaO}$ film would block the electron path in the anode. This nanostructured surface layer readily adsorbs water and has a vital role in facilitating carbon removal, making it possible to efficiently utilize higher-order hydrocarbon, $\mathrm{CO}$ and gasified carbon fuels without carbon buildup at relatively low temperatures. Unlike the above-mentioned alternative anode materials, the elemental composition of the new anode is very simple and contains no rare earth elements, which helps work towards true cost effectiveness. Moreover, $\mathrm{BaO}$ treatment can be readily incorporated into existing processes for fabrication of the state-of-the-art SOFCs based on YSZ electrolyte; it does not introduce additional processing steps, as vapour deposition is implemented during the firing of the buffer layer, and no known compatibility issues that often arise with the use of other alternative anode materials occur with the $\mathrm{BaO}$.

Although $\mathrm{BaO}$ or other alkaline earth oxides have been used as promoters for reforming catalysts ${ }^{22,23}$, their application to anodes in SOFCs has resulted in fuel cells with low power densities ${ }^{24-26}$. As alkaline oxides are electronic insulators, their addition to a Ni-YSZ anode may degrade the electrocatalytic activity of the anode. For example, the introduction of $\mathrm{CaO}$ to Ni-YSZ by mechanical mixing and $\mathrm{BaO}$ to Ni-GDC by solution impregnation reduced fuel cell power outputs, achieving a peak power density of only $\sim 0.30 \mathrm{~W} \mathrm{~cm}^{-2}$ at $750^{\circ} \mathrm{C}$ in $\mathrm{CH}_{4}$ (refs $24-26$ ). Although the performances in higherorder hydrocarbons have not been disclosed, it is reasonable to predict that the power output in $\mathrm{C}_{3} \mathrm{H}_{8}$ would be even lower stemming from inherently slower reaction kinetics? ${ }^{7}$. The critical challenge lies in creating an anode surface composed of numerous nanostructured $\mathrm{BaO} / \mathrm{Ni}$ interfaces that will promote the removal of carbon (a chemical process) on the exposed Ni surface but will not impede the charge transfer processes across the interfaces and along the surfaces (electrochemical processes) of the anode to achieve high-power output. In this study, a stable peak power density of $0.88 \mathrm{~W} \mathrm{~cm}^{-2}$ in dry $\mathrm{C}_{3} \mathrm{H}_{8}$ at $750^{\circ} \mathrm{C}$ was obtained by creating nanostructured $\mathrm{BaO} / \mathrm{Ni}$ interfaces in the anode.

\section{Results}

Characterization of $\mathrm{BaO}$ islands and $\mathrm{BaO} / \mathrm{Ni}$ interface. To characterize the detailed structure and composition of the surfaces in this new anode, we used synchrotron-based X-ray analyses because the nanostructured surface layers were very thin and undetectable using conventional X-ray analysis. Figure 1a shows typical grazing incidence angle X-ray diffraction patterns collected from the surface of a $\mathrm{BaO} / \mathrm{NiO}$ sample before and after reduction in $\mathrm{H}_{2}$. Before reduction, the main phase was cubic polycrystalline $\mathrm{NiO}$, but weak diffraction peaks related to $\mathrm{BaNiO}_{2}$ and $\mathrm{BaNiO}_{3}$ on the $\mathrm{NiO}$ surface were also observable, indicating the presence of these two phases in very low quantity. This is consistent with the known phases in the $\mathrm{BaO}-\mathrm{NiO}$ system. After reduction in $\mathrm{H}_{2}$, however, only metallic Ni was detected. No diffraction peaks related to any compounds in the $\mathrm{Ba}-\mathrm{Ni}-\mathrm{O}$ system could be detected even with extended $\mathrm{X}$-ray exposure, suggesting that any $\mathrm{Ba}$-containing phases were lacking long-range order. Our $\mathrm{Ba}_{\mathrm{III}}$-edge $\mathrm{X}$-ray absorption near-edge structure analysis (Fig. 1b) showed that $\mathrm{Ba}$ was indeed still present on the Ni surface in compound form, not as Ba metal, implying the presence of $\mathrm{BaO}$ on the Ni surface.

To reveal the local microstructures and morphologies of the nanosized $\mathrm{BaO}$ islands and the $\mathrm{BaO} / \mathrm{Ni}$ interfaces, we used electron microscopy and spectroscopy. A scanning electron microscope (SEM) examination revealed that $\mathrm{BaO}$ nanoislands were uniformly distributed on the Ni surface (Fig. 1d); the presence of $\mathrm{Ba}$ and $\mathrm{O}$ in the islands was confirmed by energy dispersive spectroscopy (EDS). The island sizes varied from a few nanometres to over $100 \mathrm{~nm}$, and the distances between two neighbouring $\mathrm{BaO}$ islands were on the order of several tens of nanometres. A cross-sectional view (Fig. 1c) and a Z-contrast image (Supplementary Fig. S1a) of a $\mathrm{BaO} / \mathrm{Ni}$ interface indicated that the thickness of the $\mathrm{BaO}$ island was up to $\sim 30 \mathrm{~nm}$. In addition, Z-contrast imaging coupled with simultaneous EDS (Supplementary Fig. S1b) was performed to confirm the presence 

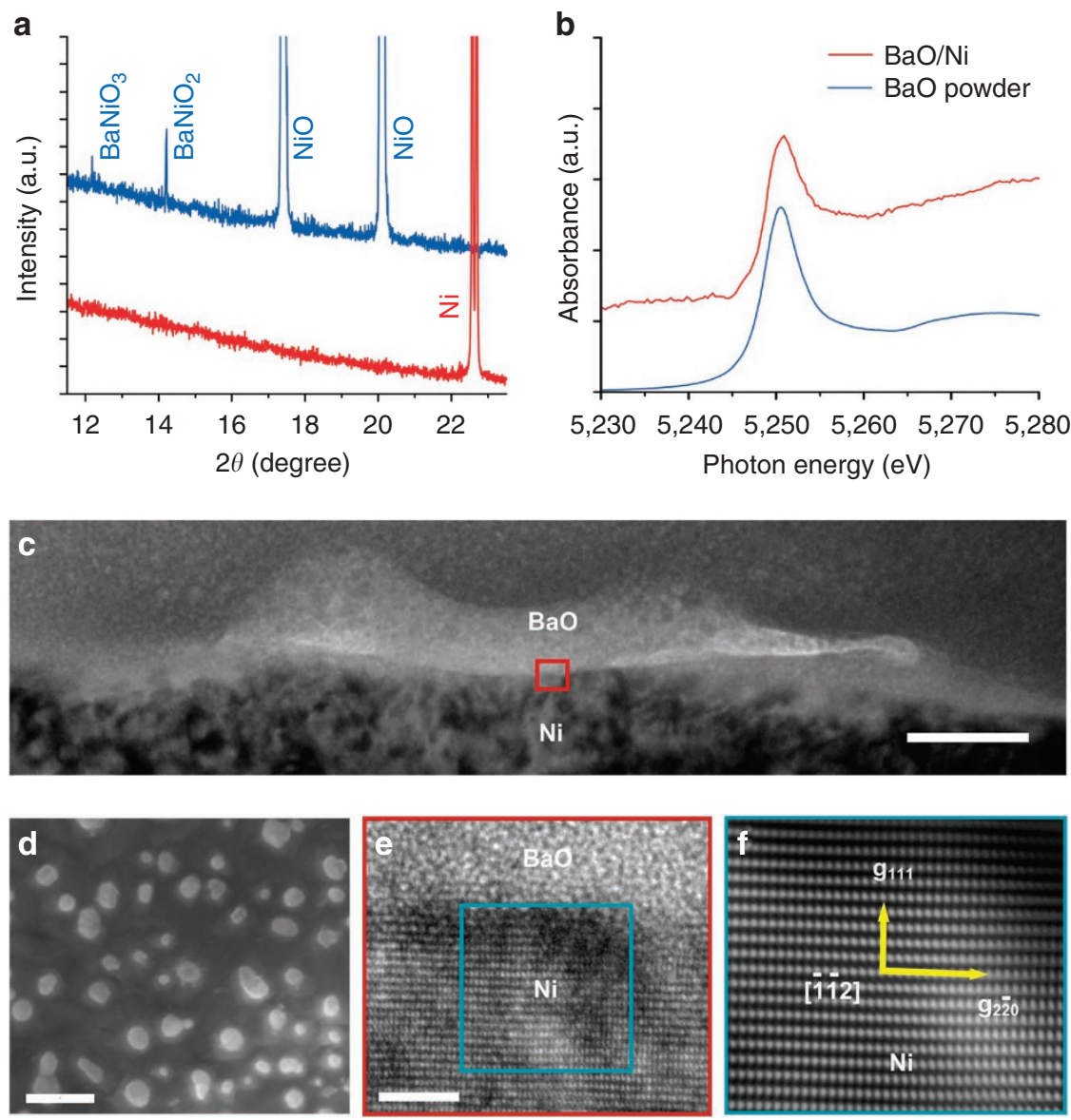

Figure 1 | Microanalysis of $\mathrm{BaO}$ nanoislands and $\mathrm{BaO} / \mathrm{Ni}$ interfaces. (a) Grazing incidence angle X-ray diffraction patterns of $\mathrm{BaO} / \mathrm{NiO}$ samples before (blue curve) and after (red curve) reduction in hydrogen. These patterns were collected at X14A beamline of National Synchrotron Light Source (NSLS). The incident angle was $0.1^{\circ}$ and the wavelength $\lambda$ was $0.72838 \AA$. (b) Ba $L_{\| 1}$-edge $X$-ray absorption near-edge structure (XANES) spectra of BaO powder and the $\mathrm{BaO} / \mathrm{Ni}$ sample. The XANES spectra were collected at X18A beamline of NSLS using reflective detection mode. The Ba $\mathrm{L}_{\| 1}$-edge $X \mathrm{ANES}$ spectrum of $\mathrm{BaO} / \mathrm{Ni}$ was an average of 13 spectra. (c) Cross-sectional view (bright-field TEM image) of a BaO/Ni interface. Scale bar, $30 \mathrm{~nm}$. (d) Top view (SEM image) of a $\mathrm{BaO} / \mathrm{Ni}$ sample. Scale bar, $200 \mathrm{~nm}$. (e) HRTEM image of the $\mathrm{BaO} / \mathrm{Ni}$ interface. Scale bar, $2 \mathrm{~nm}$. The [ $\overline{1} \overline{1} 2]$ zone axis of the Ni under the BaO island is along the viewing direction. (f) Fourier-filtered [ $[\overline{1} \overline{1} 2]$ zone axis image of the Ni under the $\mathrm{BaO}$ island.

of $\mathrm{Ba}$ and $\mathrm{O}$ in the island with a nanoprobe (full-width at half-maximum $\sim 3 \AA$ ). A selected area electron diffraction pattern, taken from the $\mathrm{BaO}$ island on the Ni surface (Supplementary Fig. S2), consisted of characteristic Ni spots and a diffuse ring, which again suggests that the $\mathrm{BaO}$ island lacked long-range order. This is also consistent with the X-ray diffraction spectrum acquired from the same sample (Fig. 1a). A high-resolution transmission electron microscopy (HRTEM) image of the interface (Fig. 1e) clearly resolved the (1 111 ) and $(2 \overline{2} 0)$ lattice fringes along the $[\overline{1} \overline{1} 2]$ zone axis of the Ni under the $\mathrm{BaO}$ island. It also revealed the amorphous appearance of the $\mathrm{BaO}$ island on the $\mathrm{Ni}$ surface. The $\mathrm{Ni}[\overline{1} 12]$ zone-axis image and amorphous appearance of the $\mathrm{BaO}$ island are consistent with the selected area electron diffraction pattern (Supplementary Fig. S2). To highlight the zone-axis fringes of the underlying Ni grain, a Fourier-filtered image of the rectangular area marked in the image (Fig. 1e) is presented in Figure 1f. A solid sphere model of the face-centred cubic lattice structure of $\mathrm{Ni}$ viewed along the $[\overline{1} \overline{1} 2]$ direction is shown in Supplementary Figure S3, where correlation between the model and HRTEM imaging is illustrated.

Power output and durability of fuel cells in $\mathrm{C}_{3} \mathrm{H}_{8}$ fuel. To examine the electrocatalytic activity of the anode with nanostructured $\mathrm{BaO} / \mathrm{Ni}$ interfaces towards hydrocarbon fuels, we investigated the current- voltage characteristics and measured the corresponding power densities of fuel cells consisting of such an anode, a YSZ electrolyte, a $\mathrm{Sm}_{0.2} \mathrm{Ce}_{0.8} \mathrm{O}_{2-\delta}$ (SDC) buffer layer and $\mathrm{La}_{0.6} \mathrm{Sr}_{0.4} \mathrm{Co}_{0.2} \mathrm{Fe}_{0.8} \mathrm{O}_{3-\delta}$ (LSCF) cathode operated with dry $\mathrm{C}_{3} \mathrm{H}_{8}$. Figure 2a shows a typical peak power density of $\sim 0.88 \mathrm{~W} \mathrm{~cm}^{-2}$ at $750{ }^{\circ} \mathrm{C}$ when dry $\mathrm{C}_{3} \mathrm{H}_{8}$ was used as the fuel, which is much higher than $\sim 0.5 \mathrm{~W} \mathrm{~cm}^{-2}$ at $750{ }^{\circ} \mathrm{C}$ reported for the latest SOFCs operated under similar conditions ${ }^{7}$. The power output is also higher than those reported in the recent literatures related to the alkaline oxide-modified anodes ${ }^{24-26}$, namely $\sim 0.30 \mathrm{~W} \mathrm{~cm}^{-2}$ at $750{ }^{\circ} \mathrm{C}$ in $\mathrm{CH}_{4}$. Again, although the performances for these cells in $\mathrm{C}_{3} \mathrm{H}_{8}$ were not reported, they should be lower than the power densities in $\mathrm{CH}_{4}$ because of more carbon atoms ${ }^{7}$. Furthermore, the cell displayed stable power output for more than $100 \mathrm{~h}$ at a constant current density of $500 \mathrm{~mA} \mathrm{~cm}^{-2}$, suggesting that the carbon deposit was largely absent on the anode. In contrast, the performance of the fuel cell with a conventional Ni-YSZ anode, tested under identical operating conditions, dropped rapidly in dry $\mathrm{C}_{3} \mathrm{H}_{8}$, due primarily to carbon buildup and deactivation of the anode (Fig. 2b). Subsequent SEM inspection of the Ni-YSZ anodes with and without $\mathrm{BaO} / \mathrm{Ni}$ interfaces showed that minimal carbon deposition occurred on the modified anode, whereas the heavy disintegration of Ni-YSZ anode induced by carbon deposits was developed during the course of fuel cell operation (Supplementary Fig. S4). 

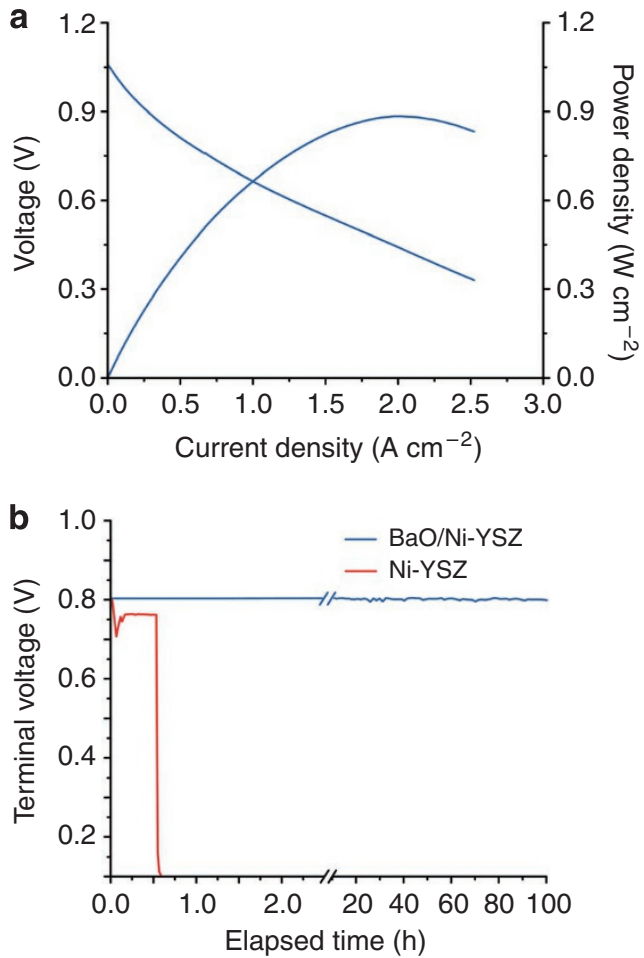

Figure 2 | Performance of fuel cells with the new anode in dry $\mathrm{C}_{3} \mathrm{H}_{8}$. (a) Typical current-voltage characteristics and the corresponding power densities measured at $750^{\circ} \mathrm{C}$ for cells with a configuration of $\mathrm{BaO} / \mathrm{Ni}-\mathrm{YSZ}$ |YSZ| SDC/LSCF when dry $\mathrm{C}_{3} \mathrm{H}_{8}$ was used as the fuel and ambient air as the oxidant. (b) Terminal voltages measured at $750^{\circ} \mathrm{C}$ as a function of time for the cells with and without $\mathrm{BaO} / \mathrm{Ni}$ interfaces operated at a constant current density of $500 \mathrm{~mA} \mathrm{~cm}^{-2}$ with dry $\mathrm{C}_{3} \mathrm{H}_{8}$ as the fuel. Water was formed on the anode by electrochemical oxidation of dry $\mathrm{C}_{3} \mathrm{H}_{8}$.

Power output and durability of fuel cells in $\mathrm{CO}$ and gasified carbon fuels. To inspect the behaviour of this new anode in $\mathrm{CO}$ and its tolerance to coking due to the $\mathrm{CO}$ disproportionation reaction, we fed $\mathrm{CO}$ fuel to test cells. Figure $3 \mathrm{a}$ shows the terminal voltage of a cell with such an anode operated at a constant current density of $500 \mathrm{~mA} \mathrm{~cm}^{-2}$ at $750{ }^{\circ} \mathrm{C}$ as a function of time when wet $\mathrm{CO}$ was used as the fuel, demonstrating a steady performance up to more than $100 \mathrm{~h}$. This cell also displayed very stable open circuit voltage $(\mathrm{OCV})$, indicating again that the presence of $\sim 3 \mathrm{v} \%$ water is sufficient to avoid carbon buildup on the anode under OCV conditions. Furthermore, this fuel cell demonstrated a peak power density of $\sim 0.70 \mathrm{~W} \mathrm{~cm}^{-2}$ at $750{ }^{\circ} \mathrm{C}$ in $\mathrm{CO}$ (Fig. 3b), which is lower than that in $\mathrm{H}_{2}$, indicating slower $\mathrm{CO}$ oxidation kinetics relative to $\mathrm{H}_{2}$ on the new anode. However, this power output represents the highest ever reported under similar testing conditions (Supplementary Table S1), suggesting that the new anode may facilitate carbon removal reactions and could efficiently convert $\mathrm{CO}$ to electricity. In contrast, a conventional Ni-YSZ anode was deactivated quickly in wet $\mathrm{CO}$ at $750^{\circ} \mathrm{C}$ and the peak power density was only $\sim 0.2 \mathrm{~W} \mathrm{~cm}^{-2}$ after $4 \mathrm{~h}$ of operation (Fig. $3 \mathrm{~b}$ ).

To evaluate the feasibility of using gasified solid carbonaceous fuels, we used a fluidized carbon bed-SOFC arrangement (Supplementary Fig. S5). Analysis of the effluent gas using mass spectrometry indicated that carbon was converted primarily to CO ( 96\%) with small amounts of $\mathrm{H}_{2}, \mathrm{H}_{2} \mathrm{O}, \mathrm{CO}_{2}$ and $\mathrm{CH}_{4}$ through wet $(\sim 3 \mathrm{v} \%$ water vapour) $\mathrm{CO}_{2}$ gasification (Supplementary Fig. S6). The fuel cell with the new anode and gasified carbon as the fuel in this configuration demonstrated a peak power density of $\sim 1.08 \mathrm{~W} \mathrm{~cm}^{-2}$ at
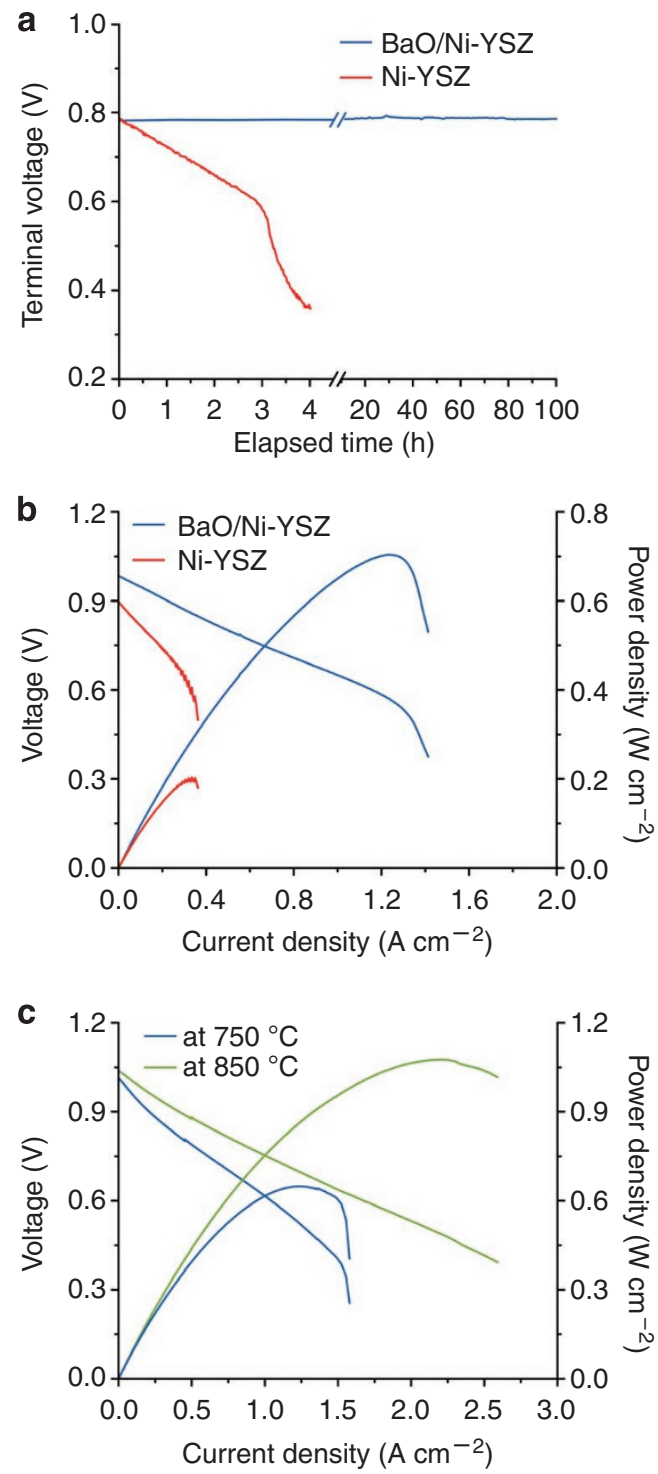

Figure 3 | Fuel cell performance in $\mathbf{C O}$ and in gasified carbon. (a) Terminal voltages measured at $750^{\circ} \mathrm{C}$ as a function of time for the cells with and without $\mathrm{BaO} / \mathrm{Ni}$ interfaces operated at a constant current density of $500 \mathrm{~mA} \mathrm{~cm}^{-2}$ with wet $\mathrm{CO}$ (with $\sim 3 \mathrm{v} \% \mathrm{H}_{2} \mathrm{O}$ ) as the fuel. (b) Typical current-voltage characteristics and the corresponding power densities measured at $750^{\circ} \mathrm{C}$ for cells with and without $\mathrm{BaO} / \mathrm{Ni}$ interfaces (after $4 \mathrm{~h}$ operation) when wet $\mathrm{CO}$ was used as the fuel and ambient air as the oxidant. (c) Typical current-voltage characteristics and the corresponding power densities measured at 850 and $750^{\circ} \mathrm{C}$ for cells with $\mathrm{BaO} / \mathrm{Ni}$ interfaces when gasified carbon was used as the fuel and ambient air as the oxidant in a fluidized carbon bed-SOFC arrangement.

$850^{\circ} \mathrm{C}$ (Fig. $3 \mathrm{c}$ ), about twice that of a cell with a conventional Ni-YSZ anode under the same conditions $\left(\sim 0.52 \mathrm{~W} \mathrm{~cm}^{-2}\right)$ and the latest cell using gasified coal with $\mathrm{CO}_{2}$ gasification $\left(\sim 0.45 \mathrm{~W} \mathrm{~cm}^{-2} \text { at } 850^{\circ} \mathrm{C}\right)^{14}$. More importantly, when the operating temperature was reduced to $750^{\circ} \mathrm{C}$, the fuel cell with the new anode still displayed a stable power output and reached a peak power density of $\sim 0.65 \mathrm{~W} \mathrm{~cm}^{-2}$ (Fig. $3 \mathrm{c}$ ). In contrast, a conventional Ni-YSZ anode cannot be stably operated in gasified carbon at this temperature, which is consistent with the observed behaviour of the same cell when CO was used as the fuel (Fig. 3a). Microanalyses of the $\mathrm{BaO} / \mathrm{Ni}$-YSZ anodes before and after operation in gasified carbon showed no observable microstructural 

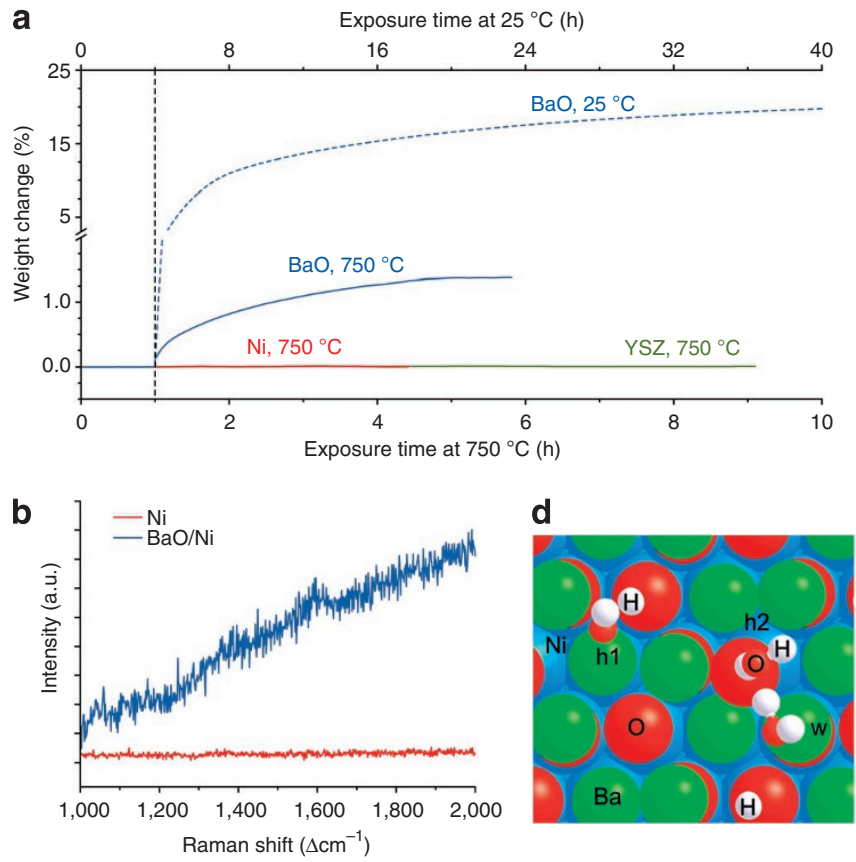

C
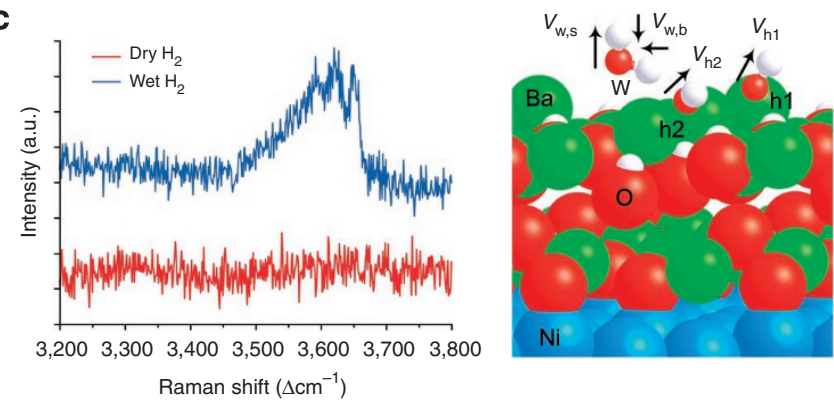

Figure 4 | Assessment of water uptake capability. (a) Typical

thermogravimetric traces for $\mathrm{Ni}, \mathrm{YSZ}$ and $\mathrm{BaO}$ powder samples in dry and wet argon with $4 \mathrm{v} \% \mathrm{H}_{2}$ at 25 and $750^{\circ} \mathrm{C}$. (b) Raman spectra recorded from $\mathrm{BaO} / \mathrm{Ni}$ and pure $\mathrm{Ni}$ samples in wet $\mathrm{H}_{2}$ (with $\sim 3 \mathrm{v} \% \mathrm{H}_{2} \mathrm{O}$ ) atmosphere at room temperature. (c) Raman spectra collected from $\mathrm{BaO} / \mathrm{Ni}$ samples in dry and wet $\mathrm{H}_{2}$ (with $\sim 3 \mathrm{v} \% \mathrm{H}_{2} \mathrm{O}$ ) atmospheres at room temperature.

(d) Top and side views for the interaction of $\mathrm{H}_{2} \mathrm{O}$ on two-layer $\mathrm{BaO}$ deposited on $\mathrm{p}(3 \times 3) \mathrm{Ni}(111)$ containing six $\mathrm{Ba}$ and six $\mathrm{O}$ atoms. ' $\mathrm{w}$ ', 'h1' and ' $h 2$ ' represent molecularly adsorbed $\mathrm{H}_{2} \mathrm{O}$ and dissociated hydroxyl species, whereas $v_{\mathrm{w}, \mathrm{b}}, v_{\mathrm{h} 1}$ and $v_{\mathrm{h} 2}$ are the vibration modes of a $\mathrm{H}_{2} \mathrm{O}$ bending and two $\mathrm{OH}$ stretchings $\left(1,594,3,716\right.$ and $\left.3,368 \mathrm{~cm}^{-1}\right)$, respectively. Large balls in Brandeis blue, green and red are $\mathrm{Ni}, \mathrm{Ba}$ and $\mathrm{O}$ of $\mathrm{BaO}$, respectively, whereas small balls in red and white are $\mathrm{O}$ from $\mathrm{H}_{2} \mathrm{O}$ and $\mathrm{H}$, respectively.

change or carbon buildup (Supplementary Fig. S4). Furthermore, a fuel cell with a $\mathrm{BaO} / \mathrm{Ni}$-YSZ anode displayed stable operation in $\mathrm{H}_{2}$ for $\sim 1,000 \mathrm{~h}$ (Supplementary Fig. S7), implying good stability of the anode under the operating conditions.

Evaluation of water uptake capability. We used thermogravimetric analysis (TGA) and Raman spectroscopy to study the interactions between water vapour and the anode materials under different conditions. TGA traces for Ni and YSZ powder samples (Fig. 4a) showed little weight change as the gas was switched from dry to wet ( $3 \mathrm{v} \%$ water vapour) argon with $4 \mathrm{v} \% \mathrm{H}_{2}$, implying that Ni-YSZ anodes hardly interact with water vapour at these temperatures. In contrast, drastic weight gains were observed for $\mathrm{BaO}$ powder samples upon exposure to the wet gas, implying that $\mathrm{BaO}$ strongly takes up water from the gas phase. This is consistent with our theoreti-

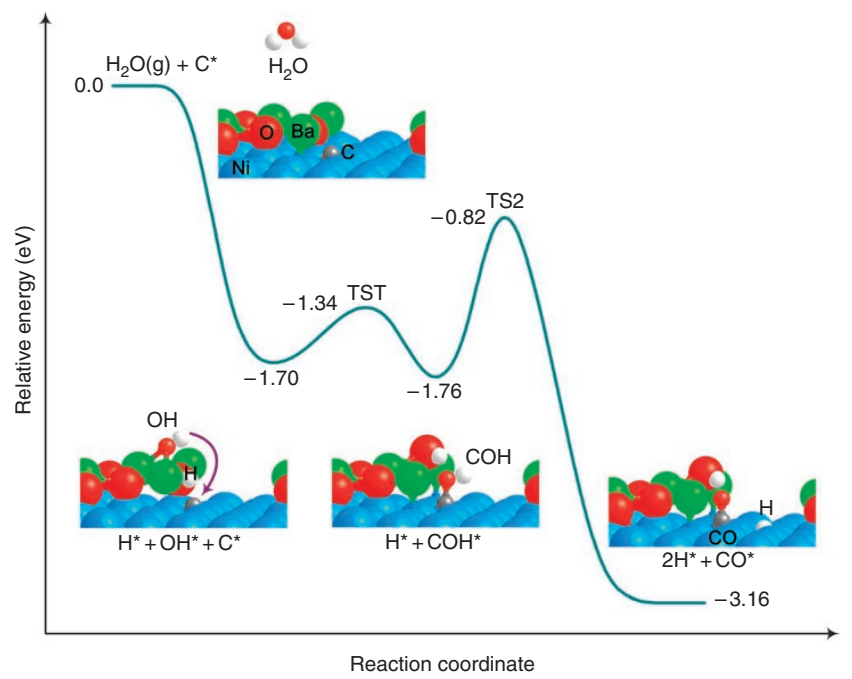

Figure 5 | DFT prediction of energy profile. The energies for removal of chemisorbed carbon species on $\mathrm{BaO} / \mathrm{Ni}(111)$ are relative to gas-phase $\mathrm{H}_{2} \mathrm{O}$ and an adsorbed carbon species on $\mathrm{BaO} / \mathrm{Ni}(111)$. ${ }^{\star}$ denotes an adsorbed species on the surface. TS, transition state.

cal predictions that $\mathrm{H}_{2} \mathrm{O}$ dissociatively adsorbs on $\mathrm{BaO}^{27}$ (Supplementary Table S2, adsorption energy: $-1.35 \mathrm{eV}$ ), but only weakly bonds to $\mathrm{Ni}^{28}$ and YSZ (Supplementary Table S2, adsorption energy: -0.32 and $-0.54 \mathrm{eV}$, respectively). It is noted that the water uptake capacity of $\mathrm{BaO}$ decreased from $\sim 20.0 \%$ at $25^{\circ} \mathrm{C}$ to $\sim 1.4 \%$ at $750^{\circ} \mathrm{C}$; however, the amount of water involved at $750^{\circ} \mathrm{C}$ is still substantial. The water uptake behaviour is also confirmed by Raman spectroscopy (Fig. 4b,c). A peak near $1,600 \mathrm{~cm}^{-1}$, corresponding to the bending mode of water ${ }^{29}$, is observed on the Raman spectra collected from a $\mathrm{BaO} / \mathrm{Ni}$ sample, but absent on that from a pure $\mathrm{Ni}$ exposed to wet $\mathrm{H}_{2}$. Further, the broad mode between 3,450 and $3,700 \mathrm{~cm}^{-1}$ on the spectrum from the $\mathrm{BaO} / \mathrm{Ni}$ sample exposed to wet $\mathrm{H}_{2}$ indicates the presence of water with weak hydrogen bonds, which is likely on the surface of the sample ${ }^{30}$. Our density functional theory (DFT) calculations with a monolayer (ML) of $\mathrm{H}_{2} \mathrm{O}$ on a $\mathrm{BaO} / \mathrm{Ni}$ surface support the Raman measurements that a $\mathrm{H}_{2} \mathrm{O}$ bending mode is at $1,594 \mathrm{~cm}^{-1}$, whereas two stretching modes of adsorbed $\mathrm{OH}$ species on $\mathrm{BaO}$ are at 3,368 and $3,716 \mathrm{~cm}^{-1}$, respectively (Fig. 4d). In contrast, these spectral features disappeared when the same sample was exposed to dry $\mathrm{H}_{2}$, further confirming the water uptake capability of the surface layers.

DFT prediction of water-mediated carbon removal. To gain insight into the mechanism of coking tolerance of this new anode, we constructed models for DFT calculations using the Vienna $a b$ initio simulation package ${ }^{31,32}$. As the $\mathrm{Ni}(111)$ surface represents the energetically most stable facet of Ni (Fig. 1f), we constructed a $\mathrm{BaO} / \mathrm{Ni}\left(\begin{array}{lll}1 & 1 & 1\end{array}\right)$ surface containing a small $\mathrm{BaO}$ chain (three $\mathrm{Ba}$ and three $\mathrm{O}$ atoms) over a three-layer $\mathrm{p}(3 \times 5) \mathrm{Ni}$ substrate $^{33}$ (Fig. 5). Our DFT calculations using this $\mathrm{BaO} / \mathrm{Ni}\left(\begin{array}{lll}1 & 1 & 1\end{array}\right)$ model show that the adsorption of $\mathrm{CO}$ on $\mathrm{BaO}$ (adsorption energy: $-0.78 \mathrm{eV}$; adsorption site: $\mathrm{O}$ atop) is much weaker than that on $\mathrm{Ni}$ (adsorption energy: $-2.60 \mathrm{eV}$; adsorption site: Ni hexagonal close-packed hollow). Given these energies, under the high temperature of the reaction, it is unlikely that the water-gas shift reaction would be effective on $\mathrm{BaO}$. On the other hand, carbon formation due to dehydrogenation of hydrocarbons or $\mathrm{CO}$ disproportionation reaction occurs readily on $\mathrm{Ni}$ catalysts ${ }^{34}$, resulting in chemically adsorbed carbon on Ni surfaces. Thus, we examined the mechanism for the removal of carbon near the BaO-like chains on $\mathrm{Ni}\left(\begin{array}{lll}1 & 1 & 1\end{array}\right)$. As schematically 
a
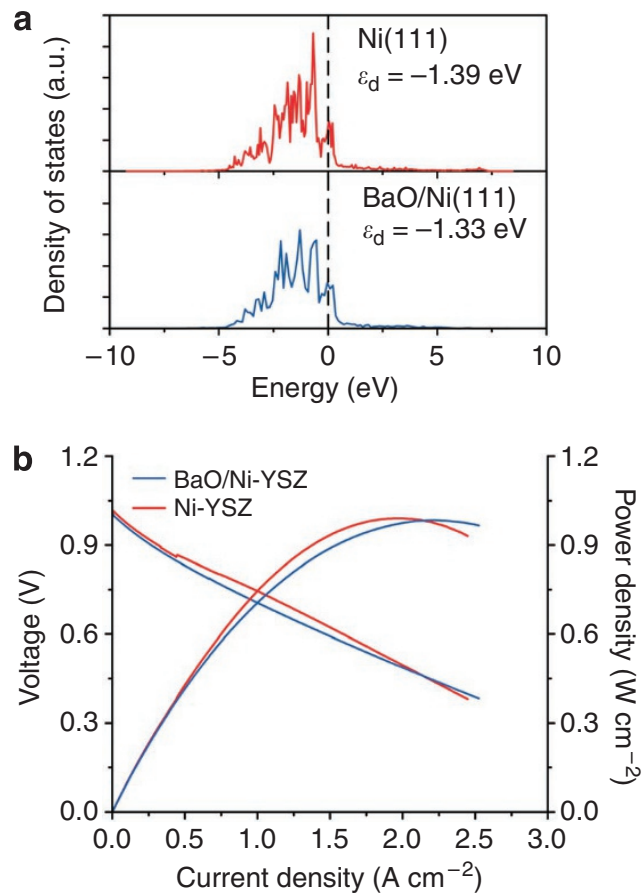

Figure 6 | Effect of $\mathrm{BaO}$ nanoislands on electronic properties of $\mathrm{Ni}$ anode. (a) Projected density of states of $\mathrm{Ni}(111)$ and $\mathrm{BaO} / \mathrm{Ni}(111)$ using DFT. The vertical dashed line is the Fermi level. The values in the figure are predicted $\mathrm{d}$-band centres based on seven bare $\mathrm{Ni}$ atoms on the topmost Ni layer. (b) Typical current-voltage characteristics and the corresponding power densities measured at $750^{\circ} \mathrm{C}$ for cells with configurations of $\mathrm{BaO} / \mathrm{Ni}-$ YSZ|YSZ| SDC/LSCF and Ni-YSZ |YSZ|SDC/LSCF when dry hydrogen was used as the fuel and ambient air as the oxidant.

shown in Figure 5, energetically the most plausible reaction pathway can be described as follows: $\mathrm{H}_{2} \mathrm{O}$ strongly adsorbs on the $\mathrm{BaO}$ site of $\mathrm{BaO} / \mathrm{Ni}(111)$, which releases energy of $-1.70 \mathrm{eV}$ and leads to a barrierless $\mathrm{O}-\mathrm{H}$ bond cleavage and hydroxylated $\mathrm{BaO}$. In contrast, $\mathrm{H}_{2} \mathrm{O}$ weakly adsorbs on the $\mathrm{Ni}$ site and a reaction barrier of $1.05 \mathrm{eV}$ has to be overcome to break the $\mathrm{O}-\mathrm{H}$ bond. Similar to a previous study ${ }^{33}$, our calculations show that $\mathrm{H}_{2} \mathrm{O}$ dissociation is more favourable near the oxide-metal interface region than on the oxide and metal surfaces. The dissociated $\mathrm{OH}$ then reacts with an adsorbed $\mathrm{C}$ on the $\mathrm{Ni}$ surface via TS1 (transition state 1 , reaction barrier: $0.36 \mathrm{eV}$ ) to form an intermediate $\mathrm{COH}$, which is subsequently dissociated to $\mathrm{CO}$ and $\mathrm{H}$ via TS2 (reaction barrier: $0.94 \mathrm{eV}$ ). Finally, $\mathrm{CO}$ and $\mathrm{H}$ diffuse to a triple-phase boundary (TPB), where they are electrochemically oxidized (combined with $\mathrm{O}^{2-}$ ) to $\mathrm{CO}_{2}$ and $\mathrm{H}_{2} \mathrm{O}$, respectively.

In addition, our DFT calculations predict that the electronic properties (for example, the d-band centre) of Ni are not adversely affected by the deposition of the $\mathrm{BaO}$ in the model with a small $\mathrm{BaO}$ chain (three $\mathrm{Ba}$ and three $\mathrm{O}$ atoms) over a three-layer $\mathrm{p}(3 \times 5) \mathrm{Ni}$ substrate; the d-band centre of pure $\mathrm{Ni}\left(\mathrm{E}_{\mathrm{d}}\right)$ is very close to that of $\mathrm{BaO} / \mathrm{Ni}$, indicating that the $\mathrm{BaO}$ deposition has little effect on the electronic properties of Ni (Fig. 6a). This is further corroborated by experimental results; the power output of a fuel cell with this new anode in $\mathrm{H}_{2}$ is similar to those of a fuel cell with a conventional NiYSZ anode under the same testing conditions (Fig. 6b), suggesting that the nanoislands of $\mathrm{BaO}$ on the $\mathrm{Ni}$ surface do not hinder the charge transfer processes on the anode. It is noted, however, that the power output of the fuel cell with the new anode in $\mathrm{H}_{2}$ is higher than that when $\mathrm{CO}$ was used as the fuel (Fig. 3c). The discrepancy in performance could be attributed primarily to the slower CO oxidation kinetics.

\section{Discussion}

As carbon forms much more readily on $\mathrm{Ni}$ than on $\mathrm{YSZ}^{35}, \mathrm{BaO} / \mathrm{Ni}$ interfaces are more important than $\mathrm{BaO} / \mathrm{YSZ}$ interfaces for carbon removal. The synchrotron-based X-ray analyses and electron microscopy have shown that $\mathrm{BaO}$ nanoislands were formed on $\mathrm{Ni}$ by vapour deposition and subsequent reduction, creating a thin, nanostructured surface layer consisting of numerous $\mathrm{BaO} / \mathrm{Ni}$ interfaces. Unlike the carbon-tolerant $\mathrm{Sn}-\mathrm{Ni}$ catalyst ${ }^{36}$ that requires full coverage of $\mathrm{Ni}$ by surface alloy to be effective, alkaline oxides ${ }^{37}$ were reported to effectively diminish the tendency of carbon buildup by partial coverage of Ni surfaces.

Cells with our new anode have shown superior power density and stability in $\mathrm{C}_{3} \mathrm{H}_{8}, \mathrm{CO}$ and gasified carbon fuels versus conventional $\mathrm{Ni}-\mathrm{YSZ}$ anodes. Although Ni-YSZ anode can indeed be operated in $\mathrm{CO}$ and gasified carbon at temperatures higher than $850^{\circ} \mathrm{C}$, which is a less severe condition for carbon buildup on Ni due to a less predominant $\mathrm{CO}$ disproportionation reaction at higher temperatures, the fuel cell without $\mathrm{BaO}$ treatment yielded much lower power density than the fuel cell with nanostructured $\mathrm{BaO} / \mathrm{Ni}$ interfaces (Fig. 3 c). In addition, as the operating temperature is lowered, much less expensive materials may be used for cell components to considerably reduce the cost while improving the reliability and operational life of fuel cells, making them more commercially viable. The demonstrated coking tolerance and high performance in $\mathrm{CO}$ at lower temperatures therefore advances the possibility for efficient conversion of gasified coal or other carbonaceous solid fuels to electricity.

Although it is also possible to avoid coking on conventional $\mathrm{Ni}-\mathrm{YSZ}$ anodes by gasification of carbon with sufficient $\mathrm{H}_{2} \mathrm{O}$ and $\mathrm{CO}_{2}$ to produce $\mathrm{H}_{2}$-rich syngas or $\mathrm{CO}_{2}$-rich gas, the amounts of $\mathrm{H}_{2} \mathrm{O}$ and $\mathrm{CO}_{2}$ required are often excessive, greatly diluting the fuel and lowering energy efficiency in addition to increasing system complexity and cost because the need for $\mathrm{H}_{2} \mathrm{O} / \mathrm{CO}_{2}$ management ${ }^{38}$. In this study, wet ( $\sim 3 \mathrm{v} \%$ water vapour) $\mathrm{CO}_{2}$ was used for carbon gasification to produce a fuel gas containing $\sim 96 \% \mathrm{CO}$ and $\sim 1 \% \mathrm{H}_{2}$. The high performance of the new anode with this fuel composition cannot be attributed to the oxidation of $\mathrm{H}_{2}$, as the cells with a conventional Ni-YSZ anode showed much lower power output under the same conditions. This is further corroborated by the findings of other studies on button-type cells with a Ni-YSZ anode (for low fuel utilization like ours) in a fuel mixture of $\mathrm{H}_{2}$ and $\mathrm{CO}^{16}$ : the anodic polarization was much larger when the $\mathrm{CO}$ content was considerably higher $(>55 \%)$ in the fuel mixture due primarily to sluggish CO oxidation and a slow shift reaction ${ }^{15,16}$, whereas the difference in performance was relatively small as the $\mathrm{H}_{2}$ content was increased from $\sim 45$ to $100 \% \mathrm{H}_{2}$. The demonstrated high-power output and coking tolerance in gasified carbon without excess $\mathrm{H}_{2} \mathrm{O} / \mathrm{CO}_{2}$ at intermediate temperatures represents a critical step towards an economically feasible fuel cell for utilization of gasified coal or carbonaceous solid fuels.

With $\mathrm{C}_{3} \mathrm{H}_{8}$ fuel, no $\mathrm{H}_{2} \mathrm{O}$ or $\mathrm{CO}_{2}$ was introduced into the new anode as the water was produced on the anode from fuel cell operation. The observed stable power outputs of the cell with this new anode in dry $\mathrm{C}_{3} \mathrm{H}_{8}$ at a current density of $500 \mathrm{~mA} \mathrm{~cm}^{-2}$ is attributed primarily to the formed water on the anode, which promoted carbon removal near the $\mathrm{BaO} / \mathrm{Ni}$ interfaces. Therefore, the high performance and tolerance to coking of the electrode at lower temperatures is attributed to the nanostructured $\mathrm{BaO} / \mathrm{Ni}$ interfaces that do not block the electrochemical processes on the anode while promoting carbon removal in the presence of a small amount of water, which was introduced either by electrochemical oxidation of $\mathrm{C}_{3} \mathrm{H}_{8}$ when dry $\mathrm{C}_{3} \mathrm{H}_{8}$ was used as the fuel or by humidification when $\mathrm{CO}$ was used as the fuel.

The TGA and Raman analyses discussed above further validated the hypothesis that the observed electrocatalytic properties of the new anode are associated with their unique capability to adsorb and/or absorb water vapour under the operating conditions. From 


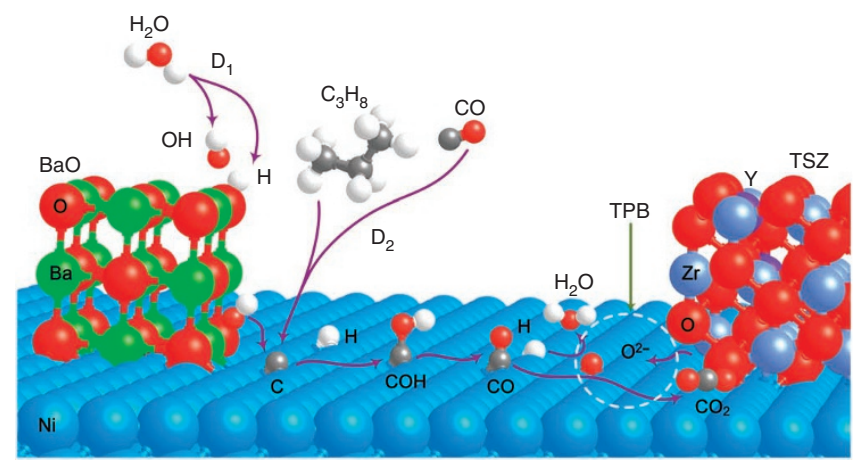

Figure 7 | Proposed mechanism for water-mediated carbon removal on the anode with $\mathrm{BaO} / \mathrm{Ni}$ interfaces. Large balls in Brandeis blue, green, red, blue grey and purple are $\mathrm{Ni}, \mathrm{Ba}, \mathrm{O}$ of $\mathrm{BaO}$ or $\mathrm{YSZ}, \mathrm{Zr}$ and $\mathrm{Y}$, respectively, whereas small balls in red, white and grey are $\mathrm{O}$ from $\mathrm{H}_{2} \mathrm{O}, \mathrm{H}$ and $\mathrm{C}$, respectively. $D_{1}$ is the dissociative adsorption of $\mathrm{H}_{2} \mathrm{O}$, whereas $\mathrm{D}_{2}$ is the dehydrogenation of hydrocarbons or the $\mathrm{CO}$ disproportionation reaction.

these analyses, it is clear that the water associated with the $\mathrm{BaO} / \mathrm{Ni}$ interfaces have a vital role in enhancing the tolerance to coking and deactivation at intermediate temperatures. These findings are in turn supported by the DFT calculations, which revealed that the water-mediated carbon removal reactions occur more favourably at the $\mathrm{BaO} / \mathrm{Ni}$ interfaces. The catalyst works synergistically: the dissociation of water takes place on the $\mathrm{BaO}$, the carbon formation occurs on the $\mathrm{Ni}$ sites of $\mathrm{BaO} / \mathrm{Ni}$ and all subsequent steps occur at or near the $\mathrm{BaO} / \mathrm{Ni}$ interfaces. Our results imply that the high performance and coking tolerance of this new anode relies heavily on the direct participation of the $\mathrm{BaO} / \mathrm{Ni}$ interfaces.

To briefly expand upon the discussion of these calculations, according to our findings, the rate-limiting step during the $\mathrm{COH}$ process is the $\mathrm{O}-\mathrm{H}$ bond cleavage of $\mathrm{COH}$. Thus, the use of new materials with $\mathrm{BaO}$ that accelerate the $\mathrm{COH}$ dissociation to $\mathrm{CO}$ and $\mathrm{H}$ may further enhance coking tolerance. On the basis of this analysis, the most probable elementary processes on the anode with nanostructured $\mathrm{BaO} / \mathrm{Ni}$ interfaces are schematically illustrated in Figure 7 and summarized as follows.

$\mathrm{H}_{2} \mathrm{O} \rightarrow \mathrm{H}_{\mathrm{ads}, \mathrm{BaO}}+\mathrm{OH}_{\mathrm{ads}, \mathrm{BaO}} \begin{aligned} & \text { dissociative adsorption of } \mathrm{H}_{2} \mathrm{O} \\ & \text { on } \mathrm{BaO}\end{aligned}$

$\mathrm{C}_{\mathrm{ads}, \mathrm{Ni}}+\mathrm{OH}_{\mathrm{ads}, \mathrm{BaO}} \rightarrow \mathrm{COH}_{\mathrm{ads}, \mathrm{Ni}} \mathrm{COH}$ formation on $\mathrm{Ni}$

$\mathrm{COH}_{\mathrm{ads}, \mathrm{Ni}} \rightarrow \mathrm{CO}_{\mathrm{ads}, \mathrm{Ni}}+\mathrm{H}_{\mathrm{ads}, \mathrm{Ni}} \rightarrow \mathrm{CO}$ and $\mathrm{H}$ formation on $\mathrm{Ni}$

$\mathrm{CO}_{\mathrm{ads}, \mathrm{Ni}} \rightarrow \mathrm{CO}_{\mathrm{tpb}} ; \quad \mathrm{H}_{\mathrm{ads}, \mathrm{Ni}} \rightarrow \mathrm{H}_{\mathrm{tpb}} \quad$ diffusion to the TPB

$\mathrm{CO}_{\mathrm{tpb}}+\mathrm{O}^{2-} \rightarrow \mathrm{CO}_{2}+2 \mathrm{e}^{-}$CO oxidation at the TPB

$2 \mathrm{H}_{\mathrm{tpb}}+\mathrm{O}^{2-} \rightarrow \mathrm{H}_{2} \mathrm{O}+2 \mathrm{e}^{-} \quad \mathrm{H}$ oxidation at the TPB

In summary, a new anode with nanostructured $\mathrm{BaO} / \mathrm{Ni}$ interfaces was fabricated by vapour deposition and subsequent reduction. These interfaces do not impede the charge transfer on the anode while promoting a water-mediated carbon removal process and enhancing its resistance to carbon buildup and deactivation under fuel cell operating conditions. Although the demonstrated higher performances and coking tolerance of this anode at lower temperatures represent a vital step towards a cost-effective fuel cell for direct conversion of hydrocarbons and gasified carbonaceous solid fuels to electricity, the impact of other contaminants on the performance of this anode is yet to be investigated. It is possible, however, that many contaminants may be effectively removed through proper cleaning, an approach feasible for stationary power generation and preferred for minimizing environmental impact.

\section{Methods}

Fabrication of fuel cells. The button-type fuel cells with a configuration of Ni-YSZ |YSZ| SDC/LSCF were fabricated in steps described as follows. First, an anode support with mixed $\mathrm{NiO}$ (Sigma-Aldrich) and YSZ powders (TOSOH; weight ratio of $55: 45)$ was fabricated by tape casting $(\sim 0.6 \mathrm{~mm}$ thick and $13 \mathrm{~mm}$ in diameter), followed by pre-firing at $800^{\circ} \mathrm{C}$ for $2 \mathrm{~h}$. Second, a thin layer of YSZ $(\sim 15 \mu \mathrm{m})$ was deposited on the anode support by a solution coating process followed by co-firing at $1,400^{\circ} \mathrm{C}$ for $5 \mathrm{~h}$. Third, a $\mathrm{Sm}_{0.2} \mathrm{Ce}_{0.8} \mathrm{O}_{2-8}$ (SDC, synthesized by a chemical coprecipitation process) buffer layer $(\sim 3 \mu \mathrm{m})$ was screen-painted on YSZ surface and fired at $1,200^{\circ} \mathrm{C}$ for $2 \mathrm{~h}$. Fourth, an LSCF (Fuel Cell Materials) slurry was screen printed onto the top of the SDC layer and fired at $1,050^{\circ} \mathrm{C}$ for $2 \mathrm{~h}$ to form a porous cathode $\left(\sim 30 \mu \mathrm{m}\right.$ thick) with an active area of $0.28 \mathrm{~cm}^{2}$. $\mathrm{BaO}$ was introduced into the NiO-YSZ structure by evaporation deposition during the firing of the SDC buffer layer. To accomplish this, $\sim 30 \mathrm{mg} \mathrm{BaO}$ powder (Sigma-Aldrich) was placed underneath a co-fired $\mathrm{NiO}$-YSZ|YSZ bilayer with the anode facing the $\mathrm{BaO}$ powder (but without physical contact) and the top surface of YSZ covered by a green SDC buffer layer; they were then fired at $1,200^{\circ} \mathrm{C}$ for $2 \mathrm{~h}$. During this process, $\mathrm{BaO}$ vapour reacts with $\mathrm{NiO}$, producing a thin layer of $\mathrm{NiO}-\mathrm{BaO}$ compounds on the $\mathrm{NiO}$ surface. On exposure to a fuel, the thin film of $\mathrm{NiO}-\mathrm{BaO}$ compounds is reduced to $\mathrm{BaO}$ nanoislands distributed on the Ni surface, creating nanostructured $\mathrm{BaO} / \mathrm{Ni}$ interfaces.

Electrochemical measurements. First, $\mathrm{Ag} / \mathrm{Pt}$ paste and $\mathrm{Ag} / \mathrm{Pt}$ wire were applied to both the anode and cathode sides for current collection. Further, each button cell was sealed on an alumina tube and heated to $750{ }^{\circ} \mathrm{C}$ in ambient air, followed by reduction of anode in $\mathrm{H}_{2}$. For evaluation of performance based on wet $\mathrm{CO}$ or dry $\mathrm{C}_{3} \mathrm{H}_{8}$ fuels, the cells were conditioned in $\mathrm{H}_{2}$ to enter steady state before the fuel was switched to wet $\mathrm{CO}$ or dry $\mathrm{C}_{3} \mathrm{H}_{8}$. Both flow rates were $10 \mathrm{ml} \mathrm{min}^{-1}$. The wet $\mathrm{CO}$ was passed through a water bubbler at room temperature, yielding $\sim 3 \mathrm{v} \%$ water vapour. For carbon fuel, we integrated a fluidized bed gasifier with a fuel cell, as schematically shown in Supplementary Figure $\mathrm{S}_{\mathrm{a}} . \mathrm{K}_{2} \mathrm{CO}_{3}$ (Sigma-Aldrich) was used as a catalyst to enhance the gasification rate and reduce the reaction temperature. The catalyst loading was $\sim 0.0024 \mathrm{~mol} \mathrm{~K}+$ per gram of activated C. First, $0.884 \mathrm{~g} \mathrm{~K}_{2} \mathrm{CO}_{3}$ was dispersed into $50 \mathrm{ml}$ deionized water. Second, $5 \mathrm{~g}$ activated carbon (Norit DLC Supra 30, Norit) was added to the solution under stirring for $24 \mathrm{~h}$, followed by drying in an oven at $80^{\circ} \mathrm{C}$. Third, $0.4 \mathrm{~g}$ carbon mixture was placed into the testing fixtures such that intimate contact with the anode surface was achieved. When the operating temperature was reached, wet $\mathrm{CO}_{2}\left(\sim 3 \mathrm{v} \% \mathrm{H}_{2} \mathrm{O}\right)$ was fed into the system after reduction of the anode in $\mathrm{H}_{2}$. All standard electrochemical experiments were performed using a Solartron 1286 electrochemical interface and a Solartron $1255 \mathrm{HF}$ frequency response analyser (Solartron). The long-term electrochemical performances of test cells were acquired using an Arbin fuel cell testing system (MSTAT).

Other characterizations. To characterize the structure, composition and morphology of the $\mathrm{BaO}$ islands and $\mathrm{BaO} / \mathrm{Ni}$ interfaces, we used synchrotron-enabled $\mathrm{X}$-ray diffraction and absorption spectroscopy, as well as advanced electron microscopy and spectroscopy (scanning transmission electron microscopy (STEM), HRTEM, SEM and EDS). First, dense $\mathrm{NiO}$ pellets were fabricated by dry pressing and sintering at $1,450^{\circ} \mathrm{C}$ for $5 \mathrm{~h}$. Thereafter, the surface of the NiO pellet was exposed to $\mathrm{BaO}$ vapour at $1,200^{\circ} \mathrm{C}$ for $2 \mathrm{~h}$, as described earlier for fabrication of full cell anodes. The $\mathrm{BaO} / \mathrm{NiO}$ sample was then reduced in dry $\mathrm{H}_{2}$ at $750^{\circ} \mathrm{C}$ for $1 \mathrm{~h}$, again, similar to the procedures used for fuel cell preparation and testing. The surface of $\mathrm{BaO} / \mathrm{NiO}$ pellets after reduction was first analysed with a LEO 1530 field emission SEM/EDS operated at $15 \mathrm{kV}$. The TEM samples were prepared with the method of focused ion beam (FIB) in situ lift-out. A thin layer containing tungsten was applied on the $\mathrm{BaO} / \mathrm{Ni}$ surface before FIB lift-out, and thus would form a strong mass contrast with the $\mathrm{BaO}$ island. The FIB was carried out with a Hitachi NB5000 FIB-SEM (Hitachi) operated at $40 \mathrm{kV}$. The cut sample was examined in an HF3300 TEM/STEM/EDS equipped with a field emission gun and operated at $300 \mathrm{kV}$. STEM and EDS were conducted with an electron probe of a size of $\sim 3 \AA$. The grazing incidence angle thin-film X-ray diffraction analysis was carried out at beamline X14A of the National Synchrotron Light Source at Brookhaven National Laboratory using a six-circle Huber diffractometer and a Si strip detector. Barium $\mathrm{L}_{\mathrm{III}}$-edge $\mathrm{X}$-ray absorption near-edge structure data were collected at beamline X18A of the National Synchrotron Light Source using the fluorescence detection mode, and the data were processed using the Athena and Artemis software packages. TGA was performed using a TA Q600 DSC-TGA system. Before comparing the water uptake ability, powders of $\mathrm{Ni}, \mathrm{BaO}$ and $\mathrm{YSZ}$ were first heated to $1,000^{\circ} \mathrm{C}$ and held for $4 \mathrm{~h}$ under dry argon with $4 \mathrm{v} \% \mathrm{H}_{2}$ to remove water and possible surface carbon dioxide. As for the Raman measurements, the $\mathrm{BaO} / \mathrm{NiO}$ and pure $\mathrm{NiO}$ samples were reduced in dry $\mathrm{H}_{2}$ gas at $500^{\circ} \mathrm{C}$ for $2 \mathrm{~h}$ using a custom-made environmental 
chamber. Raman spectra were then obtained in dry/wet $\mathrm{H}_{2}$ using a Renishaw 1000 Raman spectromicroscopy system with a 514-nm excitation wavelength. The spot size was $\sim 5 \mu \mathrm{m}$ in diameter.

Computational methods. DFT calculations with the projector-augmented wave w $^{39}$ method were carried out using the Vienna ab initio simulation package ${ }^{31,32}$. The spin-polarization calculation was applied because of the magnetic properties of Ni. Although the generalized gradient approximation with the Perdew-Wang exchange-correlation functional ${ }^{40}$ was used, the kinetic energy cutoff for a plane-wave basis set was $400 \mathrm{eV}$. To allow convergence to $0.01 \mathrm{eV}$ of the total electronic energy, the Brillouin zone was sampled with the $(3 \times 3 \times 3)$ and $(3 \times 3 \times 1)$ Monkhorst-Pack mesh ${ }^{41} \mathrm{k}$-points for bulk and surface calculations. For the two-dimensional (2D) slab model calculations, surfaces were separated by a vacuum space of $15 \AA$ in the direction perpendicular to the surface. The climbing image-nudged elastic band method $^{42,43}$ was applied to locate transition states, and potential energy surfaces were constructed accordingly. The adsorption energy $\left(E_{\text {ads }}\right)$ reported in the study was calculated as follows:

$$
E_{\text {ads }}=E[\text { adsorbate-surface }]-E[\text { surface }]-E[\text { adsorbate }]
$$

where $E$ [adsorbate-surface], $E$ [surface] and $E$ [adsorbate] are the predicted electronic energies for an adsorbed species on a surface, a bare surface and a gas-phase species such as $\mathrm{H}_{2} \mathrm{O}$.

\section{References}

1. Singhal, S. C. Advances in solid oxide fuel cell technology. Solid State Ionics 135, 305-313 (2000).

2. Atkinson, A. et al. Advanced anodes for high-temperature fuel cells. Nat. Mater. 3, 17-27 (2004).

3. la O, G. J. et al. Catalytic activity enhancement for oxygen reduction on epitaxial perovskite thin films for solid-oxide fuel cells. Angew. Chem. Int. Ed. 49, 5344-5347 (2010).

4. Hibino, T. et al. A low-operating-temperature solid oxide fuel cell in hydrocarbon-air mixtures. Science 288, 2031-2033 (2000).

5. Murray, E. P., Tsai, T. \& Barnett, S. A. A direct-methane fuel cell with a ceria-based anode. Nature 400, 649-651 (1999).

6. Park, S. D., Vohs, J. M. \& Gorte, R. J. Direct oxidation of hydrocarbons in a solid-oxide fuel cell. Nature 404, 265-267 (2000).

7. Zhan, Z. L. \& Barnett, S. A. Use of a catalyst layer for propane partial oxidation in solid oxide fuel cells. Solid State Ionics 176, 871-879 (2005).

8. Tao, S. W. \& Irvine, J. T. S. A redox-stable efficient anode for solid-oxide fuel cells. Nat. Mater. 2, 320-323 (2003)

9. Huang, Y. H., Dass, R. I., Xing, Z. L. \& Goodenough, J. B. Double perovskites as anode materials for solid-oxide fuel cells. Science 312, 254-257 (2006).

10. Ruiz-Morales, J. C. et al. Disruption of extended defects in solid oxide fuel cell anodes for methane oxidation. Nature 439, 568-571 (2006).

11. Marina, O. A., Canfield, N. L. \& Stevenson, J. W. Thermal, electrical, and electrocatalytical properties of lanthanum-doped strontium titanate. Solid State Ionics 149, 21-28 (2002).

12. Yang, L. et al. Enhanced sulfur and coking tolerance of a mixed ion conductor for SOFCs: $\mathrm{BaZr}_{0.1} \mathrm{Ce}_{0.7} \mathrm{Y}_{0.2-\mathrm{x}} \mathrm{Yb}_{\mathrm{x}} \mathrm{O}_{3-\delta}$. Science 326, 126-129 (2009)

13. Jin, Y. C., Yasutake, H., Yamahara, K. \& Ihara, M. Suppressed carbon deposition behavior in nickel/yittria-stablized zirconia anode with $\mathrm{SrZr}_{0.95} \mathrm{Y}_{0.05} \mathrm{O}_{3-\delta}$ in dry methane fuel. J. Electrochem. Soc. 157, B130-B134 (2010).

14. Gür, T. M., Homel, M. \& Virkar, A. V. High performance solid oxide fuel cell operating on dry gasified coal. J. Power Sources 195, 1085-1090 (2010).

15. Matsuzaki, Y. \& Yasuda, I. Electrochemical oxidation of $\mathrm{H}_{2}$ and $\mathrm{CO}$ in a $\mathrm{H}_{2}$ $\mathrm{H}_{2} \mathrm{O}-\mathrm{CO}-\mathrm{CO}_{2}$ system at the interface of a Ni-YSZ cermet electrode and YSZ electrolyte. J. Electrochem. Soc. 147, 1630-1635 (2000).

16. Jiang, Y. \& Virkar, A. V. Fuel composition and diluent effect on gas transport and performance of anode-supported SOFCs. J. Electrochem. Soc. 150, A942-A951 (2003).

17. Offer, G. J. \& Brandon, N. P. The effect of current density and temperature on the degradation of nickel cermet electrodes by carbon monoxide in solid oxide fuel cells. Chem. Eng. Sci. 64, 2291-2300 (2009).

18. Su, C. et al. Assessment of nickel cermets and $\mathrm{La}_{0.8} \mathrm{Sr}_{0.2} \mathrm{Sc}_{0.2} \mathrm{Mn}_{0.8} \mathrm{O}_{3}$ as solidoxide fuel cell anodes operating on carbon monoxide fuel. J. Power Sources 195, 1333-1343 (2010)

19. Wu, Y. Z., Su, C., Zhang, C. M., Ran, R. \& Shao, Z. P. A new carbon fuel cell with high power output by integrating with in situ catalytic reverse Boudouard reaction. Electrochem. Commun. 11, 1265-1268 (2009).

20. Costa-Nunes, O., Gorte, R. J. \& Vohs, J. M. Comparison of the performance of $\mathrm{Cu}-\mathrm{CeO}_{2}-\mathrm{YSZ}$ and Ni-YSZ composite SOFC anodes with $\mathrm{H}_{2}, \mathrm{CO}$, and syngas. J. Power Sources 141, 241-249 (2005).

21. Bidrawn, F. et al. Efficient reduction of $\mathrm{CO}_{2}$ in a solid oxide electrolyzer. Electrochem. Solid-State Lett. 11, B167-B170 (2008).
22. York, A. P. E., Xiao, T. C., Green, M. L. H. \& Claridge, J. B. Methane oxyforming for synthesis gas production. Catal. Rev. 49, 511-560 (2007).

23. Tomishige, K., Chen, Y. G. \& Fujimoto, K. Studies on carbon deposition in $\mathrm{CO}_{2}$ reforming of $\mathrm{CH}_{4}$ over nickel-magnesia solid solution catalysts. J. Catal. 181, 91-103 (1999).

24. Takeguchi, T. et al. Study on steam reforming of $\mathrm{CH}_{4}$ and $\mathrm{C}_{2}$ hydrocarbons and carbon deposition on Ni-YSZ cermets. J. Power Sources 112, 588-595 (2002).

25. La Rosa, D. et al. Mitigation of carbon deposits formation in intermediate temperature solid oxide fuel cells fed with dry methane by anode doping with barium. J. Power Sourc. 193, 160-164 (2009).

26. Asamoto, M., Miyake, S., Sugihara, K. \& Yahiro, H. Improvement of Ni/SDC anode by alkaline earth metal oxide addition for direct methane-solid oxide fuel cells. Electrochem. Commun. 11, 1508-1511 (2009).

27. Mei, D. Density functional theory study of surface carbonate formation on $\mathrm{BaO}(001)$. J. Phys. Chem. C 114, 1867-1874 (2010).

28. Phatak, A. A., Delgass, W. N., Ribeiro, F. H. \& Schneider, W. F. Density functional theory comparison of water dissociation steps on $\mathrm{Cu}, \mathrm{Au}, \mathrm{Ni}, \mathrm{Pd}$, and Pt. J. Phys. Chem. C 113, 7269-7276 (2009).

29. Lutz, H. D. Bonding and structure of water-molecuels in solid hydratescorrelation of spectroscopic and structural data. Struct. Bond. 69, 97-125 (1988).

30. Anedda, A., Carbonaro, C. M., Clemente, F., Corpino, R. \& Ricci, P. C. Raman investigation of surface $\mathrm{OH}$-species in porous silica. J. Phys. Chem. B 107, 13661-13664 (2003).

31. Kresse, G. \& Furthmüller, J. Efficient iterative schemes for ab initio total-energy calculations using a plane-wave basis set. Phys. Rev. B 54, 11169-11186 (1996).

32. Kresse, G. \& Hafner, J. Ab initio molecular dynamics for liquid metals. Phys. Rev. B 47, 558-561 (1993).

33. Rodriguez, J. A. et al. Activity of $\mathrm{CeO}_{\mathrm{x}}$ and $\mathrm{TiO}_{\mathrm{x}}$ nanoparticles grown on $\mathrm{Au}(111)$ in the water-gas shift reaction. Science 318, 1757-1760 (2007)

34. Shishkin, M. \& Ziegler, T. Oxidation of $\mathrm{H}_{2}, \mathrm{CH}_{4}$, and $\mathrm{CO}$ molecules at the interface between nickel and yttria-stablized zirconia: a theoretical study based on DFT. J. Phys. Chem. C 113, 21667-21678 (2009).

35. Wei, J. M. \& Iglesia, E. Isotopic and kinetic assessment of the mechanism of reactions of $\mathrm{CH}_{4}$ with $\mathrm{CO}_{2}$ or $\mathrm{H}_{2} \mathrm{O}$ to form synthesis gas and carbon on nickel catalysts. J. Catal. 224, 370-383 (2004).

36. Nikolla, E., Schwank, J. \& Linic, S. Promotion of the long-term stability of reforming Ni catalysts by surface alloying. J. Catal. 250, 85-93 (2007).

37. Bengaard, H. S. et al. Chemisorption of methane on $\mathrm{Ni}(100)$ and $\mathrm{Ni}(111)$ surfaces with preadsorbed potassium. J. Catal. 187, 238-244 (1999).

38. Ahmed, K. \& Foger, K. Kinetics of internal steam reforming of methane on Ni/YSZ-based anodes for solid oxide fuel cells. Catal. Today 63, 479-487 (2000).

39. Blöchl, P. E. Projector augmented-wave method. Phys. Rev. B 50, 17953-17979 (1994).

40. Perdew, J. P., Burke, K. \& Ernzerhof, M. Generalized gradient approximation made simple. Phys. Rev. Lett. 77, 3865-3868 (1996).

41. Monkhorst, H. J. \& Pack, J. D. Special points for Brillouin-zone integrations. Phys. Rev. B 13, 5188-5192 (1976).

42. Henkelman, G. \& Jonsson, H. Improved tangent estimate in the nudged elastic band method for finding minimum energy paths and saddle points. J. Chem. Phys. 113, 9978-9985 (2000).

43. Henkelman, G., Uberuaga, B. P. \& Jonsson, H. A climbing image nudged elastic band method for finding saddle points and minimum energy paths. J. Chem. Phys. 113, 9901-9904 (2000).

\section{Acknowledgments}

This material is based on work supported as part of the HeteroFoaM Center, an Energy Frontier Research Center funded by the US Department of Energy (DOE), Office of Science, Office of Basic Energy Sciences (BES) under Award Number DE-SC0001061. The authors acknowledge the use of the SHaRE User Facility at Oak Ridge National Laboratory (ORNL, sponsored by the Scientific User Facilities Division, US-DOE-BES) and the X14A beamline at Brookhaven National Laboratory (BNL, partially sponsored by the US-DOE-EERE, Vehicle Technologies Program, through the HTML User Program at ORNL). The DFT calculations were undertaken at BNL (supported by the US-DOEBES under Contract No. DE-AC02-98CH10886) using the computational facilities at the National Energy Research Scientific Computing (NERSC) Center and at BNL's Center for Functional Nanomaterials (CFN). The authors acknowledge partial support of the WCU program at UNIST and US National Science Foundation (under Grant No. MRI-0722730), Dr Karren More and Ms Dorothy Coffey of SHaRE at ORNL for TEM instrumentation support, and Professor M.C. Lin for CPU time.

\section{Author contributions}

M.L.L. and L.Y. conceived the project and designed the experiments. L.Y. prepared and characterized electrolytes, electrodes and fuel cells under a variety of conditions. L.Y. and 
K.B. studied TGA and Raman measurements. Y.C. and P.L. carried out DFT calculations. W.Q. performed electron microscopy analyses. H.C., J.B. and T.A.T. performed synchrotron-based X-ray analysis. M.F.L. helped with preparation of button cells.

\section{Additional information}

Supplementary Information accompanies this paper at http://www.nature.com/ naturecommunications

Competing financial interests: The authors declare no competing financial interests.
Reprints and permission information is available online at http://npg.nature.com/ reprintsandpermissions/

How to cite this article: Yang, L. et al. Promotion of water-mediated carbon removal by nanostructured barium oxide/nickel interfaces in solid oxide fuel cells. Nat. Commun. 2:357 doi: 10.1038/ncomms1359 (2011).

License: This work is licensed under a Creative Commons Attribution-NonCommercialNoDerivative Works 3.0 Unported License. To view a copy of this license, visit http:// creativecommons.org/licenses/by-nc-nd/3.0/ 